\title{
Peri-implantitis: Associated microbiota and treatment
}

\author{
Javier Ata-Ali ${ }^{1}$, María Eugenia Candel-Marti ${ }^{2}$, Antonio Juan Flichy-Fernández ${ }^{3}$, David Peñarrocha-Oltra ${ }^{2}$, \\ José Francisco Balaguer-Martinez ${ }^{4}$, María Peñarrocha Diago ${ }^{4}$
}

${ }^{1}$ DDS. Master in Oral Medicine and Surgery. Master in Oral Surgery and Implantology. Valencia University Medical and Dental School

${ }^{2}$ DDS. Resident of the Master in Oral Surgery and Implantology. Valencia University Medical and Dental School

${ }^{3}$ DDS. Master in Oral Surgery and Implantology. Valencia University Medical and Dental School

${ }^{4}$ Associate Professor of Oral Surgery. Valencia University Medical and Dental School. Valencia (Spain)

\author{
Correspondence: \\ Cirugía Bucal, \\ Clínicas Odontológicas, \\ Gascó Oliag 1 \\ 46021 - Valencia (Spain), \\ Maria.Penarrocha@uv.es
}

Received: $31 / 07 / 2010$

Accepted: $14 / 11 / 2010$

\begin{abstract}
Ata-Ali J, Candel-Marti ME, Flichy-Fernández AJ, Peñarrocha-Oltra D, Balaguer-Martinez JF, Peñarrocha MA. Peri-implantitis: Associated microbiota and treatment. Med Oral Patol Oral Cir Bucal. 2011 Nov 1;16 (7):e937-43.

http://www.medicinaoral.com/medoralfree01/v16i7/medoralv16i7p937.pdf
\end{abstract}

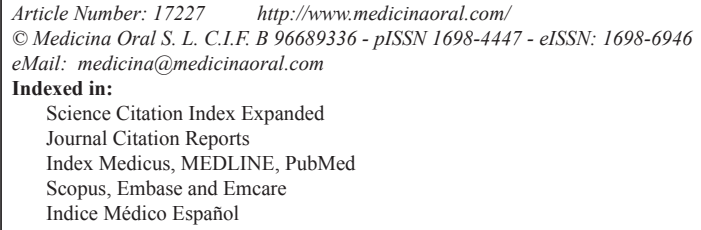

\begin{abstract}
Introduction: Peri-implantitis is a late complication of dental implant treatment, induced by microbiological changes. Since the disorder is frequent, a review is indicated of the microorganisms that influence it and of the existing treatment options.

Objective: To conduct a literature review of the microbiota associated to peri-implantitis and the existing treatment options.

Material and Method: A PubMed literature search was made of the studies on the microbiota associated to dental implants in healthy patients and patients with peri-implantitis, as well as of the latest treatment developments, using the following key words: "peri-implantitis AND microbiota", "periimplantitis AND microbiota", "periimplantitis AND treatment", and "periimplantitis AND treatment". Only clinical studies in humans were considered. The following criteria were applied for including articles in the analysis: a) for the peri-implant microbiota, the search limits were human studies after the year 2000; and b) for the treatment of peri-implantitis, the search limits were randomized and controlled clinical trials (RCTs) in humans, with a minimum follow-up of 4 months, and publication after the year 2000.

Results: A total of 18 articles were selected in relation to peri-implant microbiota, and 13 in relation to the treatment of peri-implantitis (8 involving nonsurgical mechanical treatments and 5 surgical procedures).

Conclusions: Evaluation of the literature has shown the microbiota associated to peri-implantitis to be more complex than that found under healthy peri-implant conditions - the main flora consisting of anaerobic gramnegative bacteria. No clear criteria have been identified for the diagnosis and treatment of peri-implantitis.
\end{abstract}

Key words: Peri-implant microbiota, dental implants, dental biofilm, peri-implantitis treatment, oral microbiology, peri-implant disease, peri-implant infection. 


\section{Introduction}

While dental implant treatment offers a high success rate, it is not without complications $(1,2)$. The complications associated with implant placement can be classified on a chronological basis: a) early complications, resulting from surgical trauma, inadequate bone volume, a lack of primary stability, intrabony infection or bacterial contamination of the receptor zone; and b) late complications, related to microbiological (peri-implantitis) and biomechanical changes (occlusal overload) (3).

The Sixth European Workshop in Periodontics held in 2008 defined peri-implant diseases as follows: peri-implant mucositis is the presence of inflammation of the peri-implant mucosa without signs of loss of bone support, while peri-implantitis, in addition to inflammation of the mucosa, is characterized by a loss of bone support $(4,5)$.

Mucositis appears in $80 \%$ of the patients and in $50 \%$ of the implants, while peri-implantitis is observed in 28$56 \%$ of the patients, and in $12-43 \%$ of the implants (5). Regarding the diagnosis of peri-implantitis, probing of the peri-implant sulcus is an essential element for the diagnosis of peri-implant infections, in the same way as in periodontitis. It is important to perform probing with gentle pressure (preferably 0.2-0.3 N). Other important signs are bleeding in response to probing, the presence of pus, and radiologically confirmed loss of bone support - the latter being the clinical sign confirming the presence of peri-implantitis (6).

In 1992, Socransky and Haffajee (7) modified the postulates of Koch establishing the criteria that identify periodontal pathogens. The study of the biofilm using DNA hybridization techniques made it possible to group specific bacterial species and relate them to clinical health or disease. While the "purple" (with fundamentally aerobic flora lacking mobility), "yellow" and "green" complexes are not associated to disease, the "orange" (F. nucleatum/periodontoliticum, P. intermedia, P. micros) and "red" complexes (P. gingivalis, T. forsythia, T. denticola) cause disease in the presence of virulent clones with adequate intra- and extra-chromosomal genetic information, and when found in sufficient numbers to overcome the host immune resistance. A. actinomycetemcomitans is also regarded as being periodontopathogenic, although it is not included in any group.

A PubMed literature search was made of the studies on the microbiota associated to dental implants in healthy patients and patients with peri-implantitis, as well as of the latest treatment developments, using the following key words: "peri-implantitis AND microbiota", "periimplantitis AND microbiota", "peri-implantitis AND treatment", and "periimplantitis AND treatment". Only clinical studies in humans were considered. The following criteria were applied for including articles in the analysis: a) for the peri-implant microbiota, the search limits were human studies after the year 2000; and b) for the treatment of peri-implantitis, the search limits were randomized and controlled clinical trials (RCTs) in humans, with a minimum follow-up of 4 months, and publication after the year 2000 .

A total of 18 articles were selected in relation to periimplant microbiota, and 13 in relation to the treatment of peri-implantitis (8 involving nonsurgical mechanical treatments and 5 surgical procedures).

\section{Peri-Implant Microbiota Microbiota associated to healthy peri-implant tissues}

Following exposure of the surface of the implant to the oral cavity, the corresponding biofilm is formed. This film produces an interphase between the surface of the implant and the initial microorganisms, such as for example Streptococcus mitis, Streptococcus sanguis and Streptococcus oralis. These bacteria create a series of prior conditions for the adhesion of periodontal pathogens, being able to induce the development of peri-implantitis (8).

Microbiological studies in healthy peri-implant tissues have demonstrated the presence of large proportions of coccoid cells, with a low proportion of anaerobic / aerobic species, a small number of gramnegative species, and a low detection of periodontopathogenic bacteria. However, it is also possible to find small concentrations of anaerobic gramnegative bacilli in some implants $(3,6,9)$.

\section{Microbiota associated to peri-implantitis}

The locations with peri-implant infections present a microbiota very similar to that found in periodontal disease, such as the species of the red and orange complexes, Prevotella nigrescens, Campylobacter rectus and Aggregatibacter actinomycetemcomitans, particularly serotype b, as well as Staphylococcus aureus, enteric bacilli and Candida albicans $(3,6,7,10)$ (Table 1).

The changes produced in the soft and hard tissues (clinically characterized by an increase in pocket depth and bone loss) are associated with significant changes in the composition of the subgingival microbiota, including (9): an increased total bacterial burden or load, with an increase in the proportion of Aggregatibacter actinomycetemcomitans, Fusobacterium species, Prevotella intermedia and Porphyromonas gingivalis, a decrease in the proportion of all cocci, and an important increase in the proportion of mobile organisms and spirochetes. In the study published by Shibli et al. (3) the healthy patients presented a lower total bacterial load than the periimplantitis group at both supragingival level (19x106 vs $40 \times 106)$ and at subgingival level (6.6x106 vs 22x106) $(\mathrm{p}<0.05)$. In the study by Hultin et al. (12), the evaluated periodontal pathogens Aggregatibacter actinomycetem- 
Table 1. Microbiota associated to implants in healthy patients and in subjects with peri-implantitis. Concept of peri-implantitis according to different authors.

\begin{tabular}{|c|c|c|c|c|c|}
\hline Author/Year & $\begin{array}{l}\text { Bacteria in healthy } \\
\text { implants }\end{array}$ & $\begin{array}{c}\text { Bacteria in } \\
\text { implants } \\
\text { with peri- } \\
\text { implantitis }\end{array}$ & $\begin{array}{l}\text { Diagnosis of peri- } \\
\text { implantitis }\end{array}$ & $\begin{array}{c}\text { History of } \\
\text { periodontal } \\
\text { disease/Presence } \\
\text { teeth }\end{array}$ & Technique \\
\hline $\begin{array}{l}\text { Leonhardt et al. } \\
1999(11)\end{array}$ & $\begin{array}{l}\mathrm{Pg}, \mathrm{Pi} / \mathrm{Pn}, \mathrm{Aa}, \mathrm{Ss}, \\
\text { enterococci, Candida } \\
\text { spp }\end{array}$ & $\begin{array}{l}\mathrm{Aa}, \mathrm{Se}, \mathrm{Pg} \\
\quad \mathrm{Pi}, \mathrm{kb}\end{array}$ & $\begin{array}{l}\text { Bone loss } \geq 3 \\
\text { threads. } \\
\text { Bleeding/pus } \\
\text { probing }\end{array}$ & Yes/Yes & Culture \\
\hline $\begin{array}{c}\text { Hultin et al. } 2002 \\
\text { (12) }\end{array}$ & Fss, $\mathrm{Pi}, \mathrm{Pn}, \mathrm{Ec}$ & $\begin{array}{l}\text { Pg, Pi, Tf, } \\
\text { Aa, Td }\end{array}$ & $\begin{array}{c}\text { Bone loss } \geq 3 \\
\text { threads }(1.8 \mathrm{~mm})\end{array}$ & -/Yes & DNA (12 bacteria) \\
\hline $\begin{array}{c}\text { Botero et al. } 2005 \\
\text { (10) }\end{array}$ & $\begin{array}{l}\text { Fs, Pi/Pn, Ec, } \\
\text { enterococci }\end{array}$ & $\begin{array}{l}\mathrm{Aa}, \mathrm{Tf}, \mathrm{Td}, \\
\text { enterococci, } \\
\mathrm{Pg}, \mathrm{Pi} / \mathrm{Pn}^{*}\end{array}$ & $\begin{array}{c}\text { Pocket depth } \geq 4 \\
\text { mm, Bleeding } \\
\text { upon probing }\end{array}$ & -/Yes & Culture \\
\hline $\begin{array}{l}\text { Persson et al. } 2006 \\
\text { (13) }\end{array}$ & - & $\begin{array}{c}\mathrm{Aa}, \mathrm{Pg}, \\
\mathrm{Mm}, \mathrm{Pn}, \mathrm{Fs}, \\
\mathrm{Nm}\end{array}$ & $\begin{array}{l}\text { Bone loss } \geq 2 \mathrm{~mm} . \\
\text { Pocket depth } \geq 5 \\
\mathrm{~mm} \text { with bleeding }\end{array}$ & $-/-$ & DNA (40 bacteria) \\
\hline $\begin{array}{l}\text { De Boever et al. } \\
2006(14)\end{array}$ & $\mathrm{Aa}, \mathrm{Pg}, \mathrm{Pi}, \mathrm{Tf}, \mathrm{Td}^{* *}$ & - & - & Yes/Yes & DNA probes, PCR \\
\hline $\begin{array}{l}\text { Salvi et al. } 2008 \\
\text { (15) }\end{array}$ & $\mathrm{Tf}^{*}, \mathrm{Pm}, \mathrm{Lb}, \mathrm{Cs}, \mathrm{Pi}, \mathrm{Sa}$ & - & - & $-/ Y e s$ & DNA (40 bacteria) \\
\hline $\begin{array}{c}\text { Renvert et al. } 2007 \\
\text { (16) }\end{array}$ & $\mathrm{Cs}, \mathrm{Fs}, \mathrm{Fp}, \mathrm{Lb}, \mathrm{Nm}$ & $\begin{array}{l}\mathrm{Cs}, \mathrm{Lb}, \mathrm{Nm}, \\
\mathrm{Fs}, \mathrm{Nm}, \mathrm{Fp}\end{array}$ & $\begin{array}{c}>3 \text { threads of } \\
\text { bone loss, bleeding } \\
\text { upon probing }\end{array}$ & Yes/Yes & DNA (40 bacteria) \\
\hline $\begin{array}{c}\text { Heuer et al. } 2007 \\
\text { (8) }\end{array}$ & Aa, Pg ** & - & - & $\mathrm{No} / \mathrm{Yes}$ & 16S rRNA-PCR \\
\hline $\begin{array}{c}\text { Shibli et al. } 2008 \\
\text { (3) }\end{array}$ & $\mathrm{Vp}, \mathrm{Sg}, \mathrm{Si}, \mathrm{Fp}$ & $\begin{array}{l}\mathrm{Pg}, \mathrm{Td}, \mathrm{Tf} \\
\mathrm{Fs}, \mathrm{Pi}, \mathrm{Pn}, \\
\mathrm{An}, \mathrm{Si}, \mathrm{Sm} \\
\quad *\end{array}$ & $\begin{array}{c}\text { Osteolysis }>3 \mathrm{~mm} \\
\text { and inflammatory } \\
\text { peri-implantitis } \\
\text { mucosa with } \\
\text { bleeding and/or } \\
\text { suppuration }\end{array}$ & No/Yes & DNA (36 bacteria) \\
\hline $\begin{array}{c}\text { Emrani et al. } 2009 \\
\text { (17) }\end{array}$ & $\begin{array}{l}\mathrm{Pg}, \mathrm{Pi}, \mathrm{Tf}, \mathrm{Dp}, \mathrm{Cr}, \mathrm{Pm}, \\
\text { Fs, Facultative enteric } \\
\text { gramnegative cocci }\end{array}$ & - & - & Yes/No & Culture \\
\hline $\begin{array}{l}\text { Persson et al. } 2010 \\
\text { (18) }\end{array}$ & - & $\begin{array}{l}\text { Fs, Sa, Hp, } \\
\quad \text { Aa, Tf }\end{array}$ & $\begin{array}{c}\text { Bone loss }>2.5 \\
\text { mm and pocket } \\
\text { depth } \geq 4 \mathrm{~mm} \text { with } \\
\text { bleeding/pus upon } \\
\text { probing }\end{array}$ & Yes/Yes & DNA (79 bacteria) \\
\hline
\end{tabular}

$*<0.05$

** Only these bacteria were evaluated

Aa Aggregatibacter actinomycetemcomitans, Pg Porphyromonas gingivalis, Tf Tannerella forsythia, Pi Prevotella intermedia, Td Treponema denticola, Dp Dialister pneumosintes, Cr Campylobacter rectus, Pm Peptostreptococcus micros, Fs Fusobacterium species, Cs Capnocytophaga sputigena, Lb Leptotrichia buccalis, Nm Neisseria mucosa, Mm Micromonas micros, Pn Prevotella nigrescens, Ss Staphylococcus spp, Sa Staphylococcus aureus, An Actinomyces naeslundii, Si Streptococcus intermedius, Sm Streptococcus mitis, Vp Veillonella parvula, Sg Streptococcus gordonii, Fp Fusobacterium periodonticum, Kp Klebsiella pneumoniae, Ec Eikanella corrodens, Se Staphylococcus epidermis, Hp Helicobacter pylori

$\mathrm{C}=$ Culture

DNA $=$ Checkerboard DNA-DNA hybridization technique

comitans, Porphyromonas gingivalis, Treponema denticola, Tannerella forsythia and Prevotella intermedia were present in both healthy and ill patients; however, only in the implants with peri-implantitis were these 5 bacterial species present at concentrations above 1 x 106 . Aggregatibacter actinomycetemcomitans was present in $23.5 \%$ of the locations with peri-implantitis. The authors concluded that Aggregatibacter actinomycetemcomitans and Porphyromonas gingivalis are the predominant pathogens implicated in peri-implant destruction.

Certain cases of peri-implantitis are characterized by periods of rapid and marked destruction compared with periodontitis, and a number of differences are moreover observed in terms of the host response - prompt treatment being required once such situations have been diagnosed (6). 


\section{Treatment of Peri-Implantitis}

Development of the biofilm on the surface of the dental implants plays a very important role in the appearance of peri-implantitis. The treatments proposed for periimplant disease are based on the evidence gained from the treatment of periodontitis; however, the surface of the implants facilitates adherence of the biofilm bacterial and complicates its elimination (19).

The principal objectives of the treatment of peri-implantitis are to reduce bacterial colonization of the surface of the implant, mechanically eliminate the bacterial microbiota, and introduce an ecology capable of suppressing the subgingival anaerobic flora (9). Both surgical and nonsurgical techniques have been developed to this effect.

\section{Nonsurgical Techniques}

In general terms, the treatment of peri-implantitis in the case of incipient bone loss involves the elimination of plaque and tartar, with chemical plaque control in the form of $0.12 \%$ chlorhexidine rinses every 8-12 hours during 15 days, instructions on oral hygiene, decontamination of the prosthetic abutments, antibiotic treatment, and verification that the design of the prosthesis is adequate (20).

In the articles included in our review (Table 2), a total of 122 patients were treated, with a follow-up period of 4-12 months. The patients selected for nonsurgical treatment were those presenting bleeding upon probing, with a pocket depth of $>4 \mathrm{~mm}$, radiologically confirmed bone loss of $<3 \mathrm{~mm}$, exposed implant threading, absence of mobility, and the presence of anaerobic bacteria.

The studies compared ultrasound and carbon fiber curettes; curettage with or without antibiotics; conventional scaling and the Er:YAG laser (Table 2).

\section{Mechanical treatments}

Karring et al. (24) compared the results compared the treatment results obtained with the Vector ${ }^{\circledR}$ ultrasound system and with carbon fiber curettes. After 6 months of follow-up, no significant differences were found between the two techniques, and neither proved sufficient to treat peri-implantitis. The same results were obtained by Renvert et al. (1) and Persson et al. (18). These authors evaluated 31 patients, comparing ultrasound (Vector ${ }^{\circledR}$ system) and mechanical treatment with curettes. After 6 months, both study groups showed improvement in plaque index and bleeding, though without improvement in terms of pocket depth. There were no significant differences between the groups, and the changes recorded were of no clinical relevance. In relation to bacterial load, there were no differences in the change in bacterial composition in the two groups after treatment.

Schwarz et al. (23) compared the Er:YAG laser with me- chanical treatment plus $0.2 \%$ chlorhexidine. The authors recorded significant improvements in both groups in the clinical parameters studied, though the only significant difference between the two groups was related to bleeding upon probing, which was seen to be less pronounced in the Er:YAG laser group.

Mechanical treatments associated to antibiotics

The recommended antibiotic treatments are amoxicillin, amoxicillin plus clavulanic acid, amoxicillin plus metronidazole, or erythromycin plus tetracycline, with a duration of 7-10 days (20).

The selected articles examined treatment with minocycline microspheres, the use of doxycycline, and the administration of metronidazole (Table 2). Renvert et al. (25), in the year 2006 and in 2008 (19), published two articles comparing mechanical debridement plus minocycline $1 \mathrm{mg}$ versus mechanical debridement plus $1 \mathrm{mg}$ of $1 \%$ chlorhexidine. The authors concluded that the treatments with local antibiotics improved clinical parameters such as pocket depth and bleeding, and that further studies were needed to establish how often such treatment must be repeated. Büchter et al. (22) examined the benefits of adding $8.5 \%$ doxycycline to mechanical scaling - improvements being observed in pocket depth and bleeding in the group in which the antibiotic was added.

\section{Surgical Techniques}

When bone loss is advanced or persists despite the initial treatment provided, surgical debridement of the peri-implant soft tissues is required, due to the chronic infection, with decontamination of the implant surface and the application of bone regeneration techniques to restore the lost bone (20). The surgical techniques can be divided into resection procedures and regenerative techniques, depending on the morphology and type of bone defect (26) (Table 3).

Resection techniques

Resection techniques are used when there are moderate $(<3 \mathrm{~mm})$ horizontal suprabony defects or vestibular dehiscences in a non-aesthetically compromised region. These procedures include ostectomy or osteoplasty, with the raising of an apical repositioning flap and implantoplasty $(20,26)$.

The objectives of resective surgery are to reduce pocket depth and secure adequate soft tissue morphology, in order to facilitate adequate hygiene and peri-implant health (26).

The resection technique comprises the following steps: (31): 1) removal of the supragingival bacterial plaque; 2) surgical access; 3 ) removal of granulation tissue and disintoxication of the surface of the implant; 4) correction of bone architecture; 5) modification of implant surface roughness; 6) and implantation of plaque control.

As to whether implantoplasty is or is not indicated, 
Table 2. Nonsurgical treatment of peri-implantitis.

\begin{tabular}{|c|c|c|c|c|c|c|}
\hline Author & $\begin{array}{c}\text { Diagnosis of } \\
\text { peri-implantitis }\end{array}$ & No. I & $\begin{array}{l}\text { Types of } \\
\text { treatment } \\
\text { compared } \\
\end{array}$ & $\begin{array}{c}\text { Follow- up } \\
\text { (months) }\end{array}$ & Study parameters & Conclusions \\
\hline $\begin{array}{l}\text { Tang et al. } \\
2002(21)\end{array}$ & - & 27 & $\begin{array}{c}\text {-gel } 25 \% \\
\text { metronidazole } \\
\text {-ultrasound with } \\
\text { carbon fiber tips } \\
\end{array}$ & 12 & $\begin{array}{c}\text {-plaque } \\
\text {-probing } \\
\text {-bleeding } \\
\text {-enzyme analysis }\end{array}$ & $\begin{array}{c}\text { Metronidazole } \\
\text { significantly reduces } \\
\text { pocket depth; both } \\
\text { treatments recommended }\end{array}$ \\
\hline $\begin{array}{l}\text { Büchter et } \\
\text { al. } 2004 \\
\text { (22) }\end{array}$ & $\begin{array}{c}\text {-bone loss }>50 \% \\
\text { of implant } \\
\text { surface and } \\
\text { pocket depth }>5 \\
\text { mm } \\
\end{array}$ & 48 & $\begin{array}{c}\text {-scaling } \\
\text {-scaling and } \\
8.5 \% \\
\text { doxycycline }\end{array}$ & 4 & $\begin{array}{l}\text {-recession } \\
\text {-pocket depth } \\
\text {-bleeding upon } \\
\text { probing }\end{array}$ & $\begin{array}{l}\text { Antibiotics significantly } \\
\text { reduce the } 3 \text { parameters } \\
\text { considered }\end{array}$ \\
\hline $\begin{array}{l}\text { Schwarz et } \\
\text { al. } 2005 \\
\quad(23)\end{array}$ & $\begin{array}{c}\text {-pocket depth }> \\
6 \mathrm{~mm} \\
\text {-bone loss }>3 \\
\mathrm{~mm} \\
\text {-no mobility } \\
\text {-no acute } \\
\text { periodontitis } \\
\text {-presence of } \\
\text { keratinized } \\
\text { mucosa } \\
\end{array}$ & 22 & $\begin{array}{c}\text {-Er:YAG } \\
\text {-mechanical } \\
\text { treatment plus } \\
0.2 \% \\
\text { chlorhexidine } \\
\text { digluconate }\end{array}$ & 6 & $\begin{array}{c}\text {-plaque } \\
\text {-bleeding } \\
\text {-probing } \\
\text {-gingival recession } \\
\text {-attachment loss }\end{array}$ & $\begin{array}{l}\text { Both treatment improve } \\
\text { the clinical parameters, } \\
\text { and laser significantly } \\
\text { reduces bleeding upon } \\
\text { probing }\end{array}$ \\
\hline $\begin{array}{l}\text { Karring et } \\
\text { al. } 2005 \\
\text { (24) }\end{array}$ & $\begin{array}{l}\text {-Bleeding after } \\
\quad \text { probing } \\
\text {-pocket }>5 \mathrm{~mm} \\
-1.5 \mathrm{~mm} \\
\text { radiological bone } \\
\text { loss } \\
\text {-exposed implant } \\
\quad \text { threads }\end{array}$ & - & $\begin{array}{l}\text {-Vector } \AA \\
\text {-carbon fiber } \\
\text { curettes }\end{array}$ & 6 & $\begin{array}{l}\text { - plaque } \\
\text { - bleeding } \\
\text { - probing } \\
\text { - mesial and distal } \\
\text { implant bone loss }\end{array}$ & $\begin{array}{l}\text { No significant differences } \\
\text { in the results obtained } \\
\text { with the two treatments }\end{array}$ \\
\hline $\begin{array}{l}\text { Renvert et } \\
\text { al. } 2008^{*}, \\
2006(19, \\
25)\end{array}$ & $\begin{array}{c}\text {-pocket depth }> \\
4 \mathrm{~mm} \\
\text {-bone loss }<3 \\
\text { threads } \\
\text {-microbiological } \\
\text { diagnosis }\end{array}$ & - & $\begin{array}{l}\text {-Mechanical } \\
\text { debridement: } \\
\text {-minocycline } \\
\text { microspheres } \\
\text {-gel 1\% } \\
\text { chlorhexidine }\end{array}$ & 12 & $\begin{array}{l}\text {-plaque } \\
\text {-bleeding } \\
\text {-probing } \\
\text {-microbiological } \\
\text { samples }\end{array}$ & $\begin{array}{l}\text { Minocycline } \\
\text { microspheres improve the } \\
\text { results of treatment }\end{array}$ \\
\hline $\begin{array}{l}\text { Renvert et } \\
\text { al. } 2009 \\
\text { (1) }\end{array}$ & $\begin{array}{l}\text {-pocket depth }> \\
4 \mathrm{~mm} \\
\text {-bone loss }>2.5 \\
\mathrm{~mm}\end{array}$ & - & $\begin{array}{l}\text {-titanium } \\
\text { curettes } \\
\text {-ultrasound }\end{array}$ & 6 & $\begin{array}{c}\text {-plaque } \\
\text {-probing } \\
\text {-gingival index } \\
\text {-bleeding }\end{array}$ & $\begin{array}{l}\text { Both treatment showed no } \\
\text { clinically relevant } \\
\text { changes, with no } \\
\text { differences between them }\end{array}$ \\
\hline $\begin{array}{l}\text { Persson et } \\
\text { al. } 2010 \\
\quad(18)\end{array}$ & $\begin{array}{l}\text {-pocket depth }> \\
4 \mathrm{~mm} \\
\text {-bone loss }>2.5 \\
\mathrm{~mm}\end{array}$ & - & $\begin{array}{l}\text {-titanium } \\
\text { curettes } \\
\text {-ultrasound }\end{array}$ & 6 & $\begin{array}{l}\text { Microbiological } \\
\text { samples }\end{array}$ & $\begin{array}{l}\text { Neither treatment } \\
\text { significantly reduced } \\
\text { bacterial load }\end{array}$ \\
\hline
\end{tabular}

No. I (number of implants) 
Table 3. Surgical treatment of peri-implantitis.

\begin{tabular}{|c|c|c|c|c|c|c|}
\hline Author & $\begin{array}{l}\text { Diagnosis of peri- } \\
\text { implantitis }\end{array}$ & No. I & $\begin{array}{l}\text { Types of } \\
\text { treatment } \\
\text { compared }\end{array}$ & $\begin{array}{c}\text { Follow-up } \\
\text { (months) }\end{array}$ & Study parameters & Conclusions \\
\hline $\begin{array}{l}\text { Romeo et } \\
\text { al. } 2004 \\
\text { (26) }\end{array}$ & $\begin{array}{l}\text {-suppuration or } \\
\text { bleeding } \\
\text {-pocket }>4 \mathrm{~mm} \\
\text {-no mobility } \\
\text {-horizontal } \\
\text { radiotransparency }\end{array}$ & 35 & $\begin{array}{l}\text {-resection } \\
\text { surgery }+ \\
\text { implantoplas } \\
\text { ty } \\
\text {-resection } \\
\text { surgery }\end{array}$ & 36 & $\begin{array}{c}\text {-bleeding } \\
\text {-probing } \\
\text {-pseudopockets } \\
\text {-recession }\end{array}$ & $\begin{array}{l}\text { Both treatments } \\
\text { improved the clinical } \\
\text { parameters, but } \\
\text { resection surgery plus } \\
\text { implantoplasty proved } \\
\text { better }\end{array}$ \\
\hline $\begin{array}{l}\text { Romeo et } \\
\text { al. } 2007 \\
\text { (27) }\end{array}$ & $\begin{array}{l}\text {-suppuration or } \\
\text { bleeding } \\
\text {-pocket }>4 \mathrm{~mm} \\
\text {-no mobility } \\
\text {-horizontal } \\
\text { radiotransparency }\end{array}$ & 35 & $\begin{array}{l}\text {-resection } \\
\text { surgery }+ \\
\text { implantoplas } \\
\quad \text { ty } \\
\text {-resection } \\
\text { surgery }\end{array}$ & 36 & $\begin{array}{l}\text {-mesial and distal } \\
\text { implant bone loss }\end{array}$ & $\begin{array}{l}\text { Resection surgery } \\
\text { plus implantoplasty } \\
\text { resulted in lesser bone } \\
\text { loss }\end{array}$ \\
\hline $\begin{array}{l}\text { Schwarz et } \\
\text { al. } 2006 \\
\text { (28) }\end{array}$ & $\begin{array}{c}\text {-pocket depth }>6 \\
\text { mm } \\
\text {-bone loss }>3 \mathrm{~mm} \\
\text {-no mobility } \\
\text {-no acute } \\
\text { periodontitis } \\
\text {-presence of } \\
\text { keratinized } \\
\text { mucosa }\end{array}$ & 22 & $\begin{array}{l}\text {-hydroxy- } \\
\text { apatite } \\
\text { nanocrystals } \\
\text {-Bio Oss } \AA \\
\text { plus } \\
\text { membrane }\end{array}$ & 6 & $\begin{array}{c}\text {-plaque } \\
\text {-bleeding } \\
\text {-probing } \\
\text {-gingival recession } \\
\text {-attachment loss }\end{array}$ & $\begin{array}{l}\text { Both treatments } \\
\text { offered same results } \\
\text { after } 6 \text { months }\end{array}$ \\
\hline $\begin{array}{l}\text { Schwarz et } \\
\text { al. } 2008 \\
\text { (29) }\end{array}$ & $\begin{array}{c}\text {-pocket depth }>6 \\
\text { mm } \\
\text {-bone loss }>3 \mathrm{~mm} \\
\text {-no mobility } \\
\text {-no acute } \\
\text { periodontitis } \\
\text {-presence of } \\
\text { keratinized } \\
\text { mucosa }\end{array}$ & 22 & $\begin{array}{l}\text {-hydroxy- } \\
\text { apatite } \\
\text { nanocrystals } \\
\text {-Bio Oss }{ }^{\circledR} \\
\text { plus } \\
\text { membrane }\end{array}$ & 24 & $\begin{array}{c}\text {-plaque } \\
\text {-bleeding } \\
\text {-probing } \\
\text {-gingival recession } \\
\text {-attachment loss }\end{array}$ & $\begin{array}{c}\text { Bio Oss }{ }^{\circledR} \text { plus } \\
\text { membrane offers } \\
\text { better results after } 2 \\
\text { years }\end{array}$ \\
\hline $\begin{array}{l}\text { Schwarz et } \\
\text { al. } 2009 \\
\text { (30) }\end{array}$ & $\begin{array}{c}\text {-pocket depth }>6 \\
\text { mm } \\
\text {-bone loss }>3 \mathrm{~mm} \\
\text {-no mobility } \\
\text {-no acute } \\
\text { periodontitis } \\
\text {-presence of } \\
\text { keratinized } \\
\text { mucosa }\end{array}$ & 22 & $\begin{array}{l}\text {-hydroxy- } \\
\text { apatite } \\
\text { nanocrystals } \\
\text {-Bio Oss } \AA \\
\text { plus } \\
\text { membrane }\end{array}$ & 48 & $\begin{array}{c}\text {-plaque } \\
\text {-bleeding } \\
\text {-probing } \\
\text {-gingival recession } \\
\text {-attachment loss }\end{array}$ & $\begin{array}{c}\text { Bio Oss } \AA \text { offers } \\
\text { better results after } 48 \\
\text { months }\end{array}$ \\
\hline
\end{tabular}

No. I (number of implants)

Romeo et al. (26) compared resective treatment wither alone or in combination with implantoplasty in $17 \mathrm{pa}-$ tients with 35 implants and a follow-up period of 36 months. The following clinical parameters were evaluated: bleeding, pocket depth, recession, attachment loss and radiological bone loss. The authors concluded that both procedures improve peri-implant health, though implantoplasty afforded a much better implant prognosis. In this context, bone loss with implantoplasty was $0-0.01 \mathrm{~mm}$, versus $1.44-1.54 \mathrm{~mm}$ without implantoplasty.

\section{Regenerative surgery}

Regenerative surgery is used when the implant is decisive for prosthetic preservation, or when aesthetic considerations are involved $(20,28)$.

Regenerative treatment requires prior decontamina- tion of the implant surface (20). Most studies use the concept of guided bone surgery $(29,30)$, which includes the placement of a membrane after grafting. Many bone substitutes are available, though very few randomized trials have compared them in the context of the treatment of peri-implantitis. In the studies published by Schwarz (28-30), comparisons were made of Bio Oss ${ }^{\circledR}$ and Ostim ${ }^{\circledR}$ with a collagen membrane, and involving follow-up controls after 6 months and 2 and 4 years. A total of 22 patients were included, with the evaluation of clinical parameters and radiological bone loss. After 6 months, both types of material were seen to perform equally well, though after 2 and 4 years, Bio Oss ${ }^{\circledR}$ afforded greater benefits.

In relation to the microbial flora associated with the etiology of peri-implantitis, many studies involving DNA 
identification techniques have shown the main isolated organisms to be Aggregatibacter Actinomycetemcomitans, Prevotella intermedia, Prevotella nigrescens, Porphyromonas gingivalis, Treponema denticola, Tannerella forsythia, and Fusobacterium species (3, 10-12, 16,18).

Following review of the literature, the authors reached no consensus in relation to the diagnosis of peri-implantitis in terms of bone loss or pocket depth, and likewise no criteria were established for assessing the success of treatment of peri-implant disease of for defining concrete therapeutic protocols.

\section{References}

References with links to Crossref - DOI

1. Renvert S, Samuelsson E, Lindahl C, Persson GR. Mechanical nonsurgical treatment of peri-implantitis: a double-blind randomized longitudinal clinical study. I: clinical results. J Clin Periodontol. 2009 Jul;36(7):604-9. Erratum in: J Clin Periodontol. 2009;36:1076. 2. Porras R, Anderson GB, Caffesse R, Narendran S, Trejo PM. Clinical response to 2 different therapeutic regimens to treat peri-implant mucositis. J Periodontol. 2002;73:1118-25.

3. Shibli JA, Melo L, Ferrari DS, Figueiredo LC, Faveri M, Feres M. Composition of supra- and subgingival biofilm of subjects with healthy and diseased implants. Clin Oral Implants Res. 2008;19:97582.

4. Lindhe J, Meyle J, Group D of European Workshop on Periodontology. Peri-implant diseases: Consensus Report of the Sixth European Workshop on Periodontology. J Clin Periodontol. 2008;35:282-5.

5. Zitzmann NU, Berglundh T. Definition and prevalence of periimplant diseases. J Clin Periodontol. 2008;35:286-91.

6. Heitz-Mayfield LJ, Lang NP. Comparative biology of chronic and aggressive periodontitis vs. peri-implantitis. Periodontol 2000. 2010;53:167-81.

7. Socransky SS, Haffajee AD. The bacterial etiology of destructive periodontal disease: current concepts. J Periodontol. 1992;63:32231.

8. Heuer W, Elter C, Demling A, Neumann A, Suerbaum S, Hannig $\mathrm{M}$, et al. Analysis of early biofilm formation on oral implants in man. J Oral Rehabil. 2007;34:377-82.

9. Quirynen M, De Soete M, van Steenberghe D. Infectious risks for oral implants: a review of the literature. Clin Oral Implants Res. 2002;13:1-19.

10. Botero JE, González AM, Mercado RA, Olave G, Contreras A. Subgingival microbiota in peri-implant mucosa lesions and adjacent teeth in partially edentulous patients. J Periodontol. 2005;76:1490-5. 11. Leonhardt A, Renvert S, Dahlén G. Microbial findings at failing implants. Clin Oral Implants Res. 1999;10:339-45.

12. Hultin M, Gustafsson A, Hallström H, Johansson LA, Ekfeldt A, Klinge B. Microbiological findings and host response in patients with peri-implantitis. Clin Oral Implants Res. 2002;13:349-58.

13. Persson GR, Salvi GE, Heitz-Mayfield LJ, Lang NP. Antimicrobial therapy using a local drug delivery system (Arestin) in the treatment of peri-implantitis. I: Microbiological outcomes. Clin Oral Implants Res. 2006;17:386-93.

14. De Boever AL, De Boever JA. Early colonization of non-submerged dental implants in patients with a history of advanced aggressive periodontitis. Clin Oral Implants Res. 2006;17:8-17.

15. Salvi GE, Fürst MM, Lang NP, Persson GR. One-year bacterial colonization patterns of Staphylococcus aureus and other bacteria at implants and adjacent teeth. Clin Oral Implants Res. 2008;19:242-8. 16. Renvert S, Roos-Jansåker AM, Lindahl C, Renvert H, Rutger Persson G. Infection at titanium implants with or without a clinical diagnosis of inflammation. Clin Oral Implants Res. 2007;18:509-16. 17. Emrani J, Chee W, Slots J. Bacterial colonization of oral implants from nondental sources. Clin Implant Dent Relat Res. 2009;11:10612.
18. Persson GR, Samuelsson E, Lindahl C, Renvert S. Mechanical non-surgical treatment of peri-implantitis: a single-blinded randomized longitudinal clinical study. II. Microbiological results. J Clin Periodontol. 2010;37:563-73.

19. Renvert S, Roos-Jansåker AM, Claffey N. Non-surgical treatment of peri-implant mucositis and peri-implantitis: a literature review. J Clin Periodontol. 2008;35:305-15.

20. Sánchez-Gárces MA, Gay-Escoda C. Periimplantitis. Med Oral Patol Oral Cir Bucal. 2004;9 Suppl:69-74, 63-9.

21. Tang Z, Cao C, Sha Y, Lin Y, Wang X. Effects of non-surgical treatment modalities on peri-implantitis. Zhonghua Kou Qiang Yi Xue Za Zhi. 2002;37:173-5.

22. Büchter A, Meyer U, Kruse-Lösler B, Joos U, Kleinheinz J. Sustained release of doxycycline for the treatment of peri-implantitis: randomised controlled trial. Br J Oral Maxillofac Surg. 2004;42:43944.

23. Schwarz F, Sculean A, Rothamel D, Schwenzer K, Georg T, Becker J. Clinical evaluation of an Er:YAG laser for nonsurgical treatment of peri-implantitis: a pilot study. Clin Oral Implants Res. 2005; 16:44-52.

24. Karring ES, Stavropoulos A, Ellegaard B, Karring T. Treatment of peri-implantitis by the Vector system. Clin Oral Implants Res. 2005;16:288-93.

25. Renvert S, Lessem J, Dahlén G, Lindahl C, Svensson M. Topical minocycline microspheres versus topical chlorhexidine gel as an adjunct to mechanical debridement of incipient peri-implant infections: a randomized clinical trial. J Clin Periodontol. 2006;33:362-9.

26. Romeo E, Ghisolfi M, Carmagnola D. Peri-implant diseases. A systematic review of the literature. Minerva Stomatol. 2004;53:21530.

27. Romeo E, Lops D, Chiapasco M, Ghisolfi M, Vogel G. Therapy of peri-implantitis with resective surgery. A 3-year clinical trial on rough screw-shaped oral implants. Part II: radiographic outcome. Clin Oral Implants Res. 2007;18:179-87.

28. Schwarz F, Bieling K, Latz T, Nuesry E, Becker J. Healing of intrabony peri-implantitis defects following application of a nanocrystalline hydroxyapatite (Ostim) or a bovine-derived xenograft (BioOss) in combination with a collagen membrane (Bio-Gide). A case series. J Clin Periodontol. 2006;33:491-9.

29. Schwarz F, Sculean A, Bieling K, Ferrari D, Rothamel D, Becker J. Two-year clinical results following treatment of peri-implantitis lesions using a nanocrystalline hydroxyapatite or a natural bone mineral in combination with a collagen membrane. J Clin Periodontol. 2008;35:80-7.

30. Schwarz F, Sahm N, Bieling K, Becker J. Surgical regenerative treatment of peri-implantitis lesions using a nanocrystalline hydroxyapatite or a natural bone mineral in combination with a collagen membrane: a four-year clinical follow-up report. J Clin Periodontol. 2009;36:807-14.

31. Mombelli A, Lang NP. Antimicrobial treatment of peri-implant infections. Clin Oral Implants Res. 1992;3:162-8. 